Jurnal Akuntansi dan Bisnis: Jurnal Program Studi Akuntansi 7 (2) November 2021

ISSN 2443-3071 (Print) ISSN 2503-0337 (Online) DOI: $10.31289 /$ iab.v7i2.5665

\title{
JURNAL AKUNTANSI DAN BISNIS
} Jurnal Program Studi Akuntansi

\section{Model Perilaku Konsumsi Lintas Generasi dalam Bertransaksi Digital}

\section{Consumption Behavior Models Of-Cross-Generation on Digital Transaction}

\author{
Afni Sirait 1) *, Ida Ayu Purnama 1) \& Crescentiano Agung Wicaksono ${ }^{2)}$
}

1) Jurusan Akuntansi, Ekonomi dan Bisnis, Universitas Pembangunan Nasional "Veteran" Yogyakarta, Indonesia

2) Jurusan Akuntansi, Fakultas Ekonomi, Akademi Akuntansi YKPN, Indonesia

Diterima: 13 Agustus 2021 Direview: 13 Agustus 2021 Disetujui: 25 September 2021

*Coresponding Email: afni.sirait@upnvk.ac.id

\begin{abstract}
Abstrak
Perubahan gaya dan tren konsumsi masyarakat saat ini dipengaruhi secara mendasar dari penggunaan teknologi. Pandemi COVID-19 menjadi salah satu tearning point yang menjelaskan bahwa teknologi menjadi kebutuhan pokok saat ini. Transaksi digital menjadi hal yang tidak asing bahkan menyapa semua lintas generasi. Penelitian ini bertujuan untuk menganalisis model perilaku konsumsi dari setiap hirarki generasi dalam bertransaksi digital. Responden dari penelitian ini adalah generasi X, Y, dan Z yang masing-masing terdiri dari 50 responden. Metode analisis data menggunakan Path Analysis dengan menggunakan software statistik WarmPLS 6.0. Hasil pengolahan data menunjukkan bahwa tidak ada hubungan langsung maupun tidak langsung dari faktor budaya dengan keinginan bertransaksi digital generasi X, Y, dan Z meskipun dimediasi variabel perilaku konsumsi. Faktor psikologi mempengaruhi generasi $Y$ dan $\mathrm{Z}$ dalam bertransaksi secara digital dengan dimediasi secara penuh oleh variabel perilaku konsumsi. Penelitian ini memberikan tambahan pengetahuan tentang model perilaku yang mempengaruhi dan memotivasi ketiga generasi dalam bertransaksi digital.
\end{abstract}

Kata Kunci: Transaksi Digital; Perilaku Konsumsi; Hirarki Generasi.

\begin{abstract}
Changes in people's consumption styles and trends today are fundamentally influenced by the use of technology. The COVID-19 pandemic is one of the tearing points that explains that technology is a basic need today. Digital transactions are familiar and even greet all generations. This study aims to analyze the consumption behavior model of each generation hierarchy in digital transactions. Respondents from this study were generations $X, Y$, and $Z$, each of which consisted of 50 respondents. Data analysis method using Path Analysis using WarmPLS 6.0 statistical software. The results of data processing show that there is no direct or indirect relationship from cultural factors to the desire to transact digitally for generations $X, Y$, and $Z$ although it is mediated by consumption behavior variables. Psychological factors influence generations $Y$ and $Z$ in digitally transacting fully mediated by consumption behavior variables. This study provides additional knowledge about behavioral models that influence and motivate the three generations in digital transactions.
\end{abstract}

Keywords: Digital Transaction; Consumption Behavior; Generation Hierarchy.

How to Cite: Sirait, A. Purnama, I.A. \& Wicaksono, C.A. (2021). Model Perilaku Konsumsi Lintas Generasi dalam Bertransaksi Digital. Jurnal Akuntansi dan Bisnis: Jurnal Program Studi Akuntansi. 7(2): 196-206 


\section{PENDAHULUAN}

Perusahaan teknologi menjadi salah satu perusahaan yang saat ini banyak digandeng untuk menciptakan dan menyediakan alat pemuas kebutuhan terutama untuk customer yang sangat pemilih. Hal ini menjadi salah satu alternatif pilihan untuk dapat memenangkan pasar yang semakin kompetitif. Rapp, Tirassa, \& Tirabeni (2019) menguji beberapa topik yang berhubungan dengan penggunaan teknologi. Topik pertama menyebutkan bahwa bidang keuangan dan sumber daya digital memiliki hubungan yang mendasar terhadap layanan keuangan digital yang didukung perangkat digital, fasilitas perbankan berbasis seluler, jangkauan TIK, dan terhubung dengan intenet. Topik kedua pentingnya pengetahuan yang memadai terkait layanan keuangan digital, keamanan data elektonik untuk menghindari adanya pencurian data. Topik ketiga adalah layanan digital yang saat ini ada di masyarakat merupakan perpaduan inklusi sosial dan digital.

Otoritas Jasa Keuangan (2017) menjelaskan bahwa perusahaan perbankan memberikan banyak fasilitas perbankan berbasis teknologi dalam pemenuhan kebutuhan saat ini dapat dilakukan dengan berbelanja melalui berbagai market-place. Flatform yang disediakanpun beraneka-ragam dengan cara dan gaya marketing yang berbeda-beda. Sejalan dengan hal itu, mobilitas masyarakat saat ini juga semakin tinggi. Mobilitas yang tinggi ini menjadi salah satu pemicu bahwa para produsen harus dapat menyediakan layanan dan fasilitas yang cepat, tepat, efektif, efesien, bahkan bernilai tambah.

Migrasi penggunaan teknologi dalam dunia perbankan merupakan sebuah upaya untuk menekan aksesibilitas dalam waktu dan ruang. Selain itu transformasi ini membantu meningkatkan trasparansi, menekan biaya, customer yang semakin cerdas baik secara pengetahuan dan finansial, transfer layanan yang berkualitas kepada pelanggan, keamanan data, dan wujud customer relationship yang dapat diberikan oleh perusahaan (Filotto, Caratelli, \& Fornezza, 2021).

Fasilitas perbankan berbasis teknologi ini memberikan kemudahan bagi nasabah untuk bertransaksi. Multi transaksi yang dapat dilakukan ini dapat dilakukan melalui gawai yang dimiliki para nasabah. Hal ini mendorong semakin eksisnya penggunaan flatform berbelanja online. Masyarakat melakukan transaksi mulai dari memilih, membayar, dan mengirim barang dari gawai yang dimiliki. Pengunaan platform ecommerce di Indonesi kian meningkat karena kemudahan dari penggunaan teknologi. Suyudi (2021) meringkas pernyataan Handhika Jahja (Direktur Shoppe Indonesia) dalam siaran pers yaitu tren pembayaran digital yang meningkat, sektor logistik atau pengiriman barang yang semakin meningkat, dan strategi industri ritel yang semakin inovatif ditengah masa pandemi.

Iskandar (2021) melakukan survei tentang penggunaan uang elektronik di Indonesia. Pandemi membantu meningkatkan penggunaan uang elektronik meningkat $24,42 \%$ tahun ke tahun. Penggunaan uang elektronik banyak digunakan untuk pembelian makanan delivery disusul dengan pembayaran transportasi online. Uang elektronik yang banyak digunakan saat ini adalah ShopeePay, diikuti OVO, Gopay, Dana, dan LinkAja.

Kasasa (2021) menjelaskan bahwa hirarki antar generasi berbeda dikarenakan media consumption, banking habits, shaping events dan financial horizon. Sipayo (2017) menjelaskan hirarki generasi berdasarkan tahun lahir yaitu generasi baby boomer kelahiran tahun 1945 - 1960, generasi X kelahiran tahun 1961 - 1980, generasi Y kelahiran tahun 1981 - 1995, dan generasi Z kelahiran setelah tahun 1995. Pengelompokkan generasi berdasarkan tahun kelahiran mempengaruhi beberapa faktor yaitu cara pandang, cara menjalin hubungan, tujuan hidup, kesadaraan diri, penguasaan 
IT, nilai-nilai kehidupan, dan karakteristik yang menjadi hal mendasar (Bencsik, Juhász, \& Horváth-Csikós, 2016).

Putra (2016) menyebutkan bahwa generasi $\mathrm{Y}$ dan $\mathrm{Z}$ merupakan generasi yang sangat melekat dengan teknologi. Generasi $\mathrm{Z}$ merupakan generasi yang sangat mengandalkan data dan informasi dalam kehidupan sehari-hari. Berbeda dengan generasi $X$, generasi ini lahir pada masa transisi penerapan teknologi dalam kehidupan sehari-hari. Perbedaan generasi faktanya menjadi salah satu faktor yang mempengaruhi perilaku dalam penggunaan teknologi.

Peningkatan transaksi digital dengan penggunaan uang elektronik menjadi sebuah kebutuhan saat ini. Penggunaan gawai yang semakin mendukung pemenuhan kebutuhan ini memberikan kemudahaan yang dapat dinikmati berbagai jenis demografi yang tercipta di masyarakat. Wang, Wang, Tao, \& Xie (2021) menjelaskan bahwa perilaku konsumsi akan berhubungan dengan keputusan untuk mendapatkan, menggunakan, dan menghentikan penggunaan barang atau jasa yang dibeli atau dikonsumsi yang keputusan tersebut dapat berubah dikarenakan layanan internet yang berbayar. Perilaku konsumsi menurut Nguyen, de Leeuw, \& Dullaert (2018) menjelaskan perilaku konsumsi diartikan sebagai bentuk pembelian, pembelian kembali, dan pengembalian produk. Perilaku konsumsi ini akan dipengaruhi manajemen inventaris, pengiriman, dan pengelolaan pengembalian jarak jauh.

Peña-García et al., (2020) menjelaskan bahwa perilaku konsumsi dapat berbeda dipengaruhi oleh budaya nasional, adat-istiadat, nilai dan norma sejak lahir, dan wilayah tempat tinggal. Sedangkan penelitian yang dilakukan oleh Trisnani, Adriyai, Wandansari, \& Isthika (2019) menjelaskan bahwa perilaku konsumsi remaja dipengaruhi oleh gaya hidup hedonisme yang tinggi dan berbanding lurus dengan tingginya perilaku konsumsi.

Victor, Thoppan, Nathan, \& Maria (2018) menemukan tujuh faktor yang mempengaruhi perubahan perilaku konsumsi dalam berbelanja online. Faktor yang mempengaruhi tersebut ialah pengalaman berbelanja, keamanan data pribadi, perubahan harga, strategi pembelian, persepsi tentang keadilan harga, intensi balasan dan intensi untuk melindungi diri. Auf, Meddour, Saoula, \& Majid (2018) menambahkan bahwa faktor harga, budaya, motivasi, dan orientasi kepercayaan menjadi hal yang mempengaruhi perilaku konsumsi.

Nilekani, Khan, Sansi, Sharma, \& Jain (2019) menyebutkan bahwa transaksi berbasis digital adalah pembayaran yang menggunakan metode elektronik dalam pengiriman atau menerima uang. Sarkar (2018) dan Hanninen (2020) menjelaskan bahwa digitalisasi merupakan hasil dari penggunaan teknologi digital yang memberikan perubahan pada model bisnis. Perubahan ini menjadi hal baru yang memberikan peluang dan potensi pendapatan baru.

Syahadiyanti \& Subriadi (2018) menyatakan bahwa perubahan yang diberikan teknologi meningkatkan efesiensi secara ekonomi dalam hal pembayaran dikarenakan akurasi dan kecepatan pembayaran. Saragih \& Nopriadi (2019) menjelaskan bahwa penggunaan transaksi digital, penggunaan teknologi, transaksi pembayaran online dipengaruhi secara signifikan oleh budaya. Hasil penelitian yang dilakukan oleh Rachmawati, Kartawinata, Wijaya, \& Hasbi (2020) menunjukkan bahwa budaya memberikan pengaruh untuk penggunaan pembayaran secara digital dengan perolehan nilai 79,5\%

H1a: Faktor budaya berpengaruh signifikan terhadap penggunaan transaksi digital generasi $\mathrm{X}$ dimediasi perilaku konsumsi.

$H_{1 b:}$ Faktor budaya berpengaruh signifikan terhadap penggunaan transaksi digital generasi Y dimediasi perilaku konsumsi. 


\section{H1c: Faktor budaya berpengaruh signifikan terhadap penggunaan transaksi digital generasi $\mathrm{Z}$ dimediasi perilaku konsumsi.}

Park (2019) menjelaskan bahwa berbelanja secara virtual dapat dirasakan oleh customer sebagai bentuk tindakan psikologis jarak jauh terutama dalam penggunaan uang digital. Hal yang sama disampaikan oleh Kulkarni, Varma, \& V (2021) menjelaskan bahwa hal yang dapat mempengaruhi perilaku transaksi digital customer bisa saja karena penolakan dari sebuah inovasi atau pertimbangan atas perubahan sebuah perilaku secara psikologis.

H2a: Faktor psikologi berpengaruh signifikan terhadap penggunaan transaksi digital generasi $\mathrm{X}$ dimediasi perilaku konsumsi.

$H_{2 b:}$ Faktor psikologi berpengaruh signifikan terhadap penggunaan transaksi digital generasi Y dimediasi perilaku konsumsi.

$\mathrm{H}_{2 \mathrm{c}}$ Faktor budaya berpengaruh signifikan terhadap penggunaan transaksi digital generasi $\mathrm{Z}$ dimediasi perilaku konsumsi.

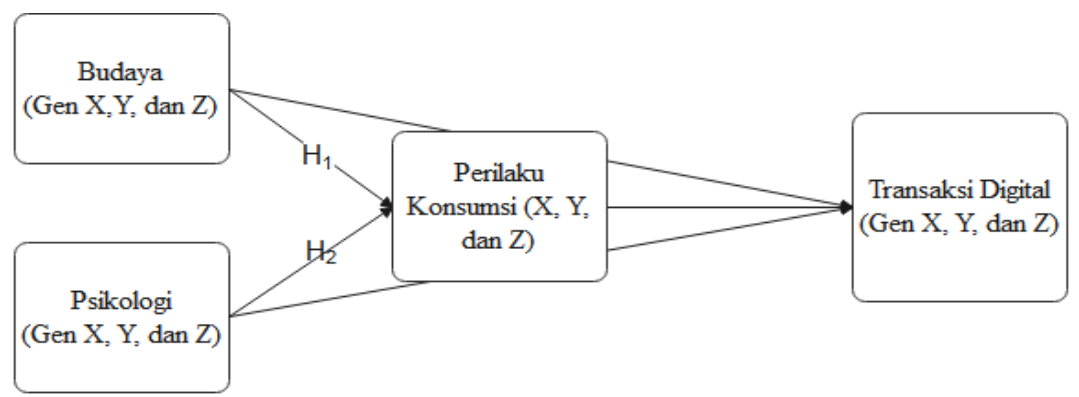

Gambar 1. Rerangka Hipotesis

Sumber: Deskripsi Peneliti

\section{METODE PENELITIAN}

Penelitian ini merupakan penelitian dengan pendekatan kuantitatif dan menggunakan kuesioner sebagai alat pengumpulan data. Disman, Ali, \& Syaom Barliana (2017) menjelaskan bahwa penelitain dengan pendekatan kuantitatif merupakan pendekatan yang akan menjelaskan bagaimana peneliti menggunakan metodelogi dan menjelaskan alasan memilih metodelogi tersebut. Pendekatan ini dipilih kerena bertujuan untuk melakukan pengujian dan analisis sebab-akibat dari hipotesis yang dibagun Apuke (2017). Data yang dikumpulkan akan dianalisis menggunakan metode Path Analysis dengan alat analisis data WarpPLS 6.0. Pemilihan alat analisis ini dilakukan untuk menguji hubungan langsung, tidak langsung, signifikan dan tidak signifikan antar variabel yang digunakan.

Teori yang akan digunakan dalam penelitian ini adalah teori budaya, psikologi, perilaku konsumsi dan berilaku bertransaksi digital (Saragih \& Nopriadi (2019), Park (2019), Peña-García et al., (2020) dan Wang et al.(2021). Variabel yang dibangun dalam penelitian ini terdiri dari 1 variabel endogen (transaksi digital), 2 variabel eksogen (budaya dan psikologi), dan 1 variabel mediasi (perilaku konsumsi). Carrión, Nitzl, \& Roldán (2017) variabel mediasi tersebut akan digunakan untuk mengidentifikasi pengaruh yang diberikan secara penuh, parsial, atau tidak memediasi. Kuesioner yang disusun dengan menyajikan pertanyaan deskriptif dan pernyataan dengan pengukuran skala. Skala pengukuran yang digunakan dalam kuesioner menggunakan skala likert 1-7 dengan range sangat tidak setuju hingga sangat setuju. 
Sampel dari penelitian ini adalah 50 responden generasi $X, 50$ responden generasi Y, dan 50 responden generasi Z. Pemilihan responden untuk penarikan sampel menggunakan metode purposive sampling dengan ketentuan bahwa responden tersebur memiliki atau menggunakan fasilitas digital perbankan (seperti SMS banking, internet banking, mobile banking, dll), menggunakan e-commerce (seperti Shoppe, Lazada, Tokopedia, dll), dan melakukan transaksi digital dengan perpaduan pembayaran dan pembelian secara digital minimal sebanyak 10 kali dalam 6 bulan terakhir.

\section{HASIL DAN PEMBAHASAN}

Responden dari penelitian ini sebanyak 150 responden yang terbagi dalam 50 responden generasi $\mathrm{X}, 50$ responden generasi $\mathrm{Y}$, dan 50 responden generasi $\mathrm{Z}$. Jumlah responden wanita secara keseluruhan sebesar 96 responden (64\%), sedangkan responden pria 54 responden (36\%). Demografi responden menyajikan responden yang memiliki 2 atau lebih akun perbankan mulai dari generasi X, Y, dan, Z adalah 43, 45, dan 29 responden. Responden yang memiliki 1 akun perbankan, paling banyak di generasi Z dengan jumlah 21 responden. Responden generasi $X$ didominasi responden berpendidikan Strata 2 sebanyak 26 responden (52\%), generasi Y didominasi responden berpendidikan Strata 2 sebanyak 22 responden (44\%), dan generasi Z didominasi responden berpendidikan SMA sebanyak 33 reponsen (66\%).

Pengujian pertama dilakukan dengan melihat hasil pengolahan combined loadings and cross-loadings. Pengukuran ini dilakukan untuk menguji indikator terhadap indikator tersebut, sehingga indikator yang digunakan dapat dijadikan alat untuk pengumpulan data dalam penelitian. Hasil pengukuran ini memiliki nilai standar minimal atau lebih besar dari 0,70. Hasil dari pengujian untuk Gen X ditemukan bahwa indikator variabel untuk PK4 (Perilaku Konsumsi item ke-4) dan PK5 (Perilaku Konsumsi item ke-5) memiliki nilai dibawah 0,70. Tabel 1 dibawah ini menyajikan hasil pengolahan data combine loadings and cross-loadings.

Tabel 1. Indicator Loadings and Cross-Loadings Gen $X$

\begin{tabular}{|c|c|c|c|c|c|c|c|}
\hline & FB & FP & PK & PDB & Type (as defined) & SE & P value \\
\hline FB1 & $\mathbf{( 0 . 9 3 2 )}$ & -0.010 & 0.177 & -0.126 & Reflective & 0.099 & $<0.001$ \\
\hline FB2 & $\mathbf{( 0 . 8 2 6 )}$ & 0.410 & 0.000 & -0.472 & Reflective & 0.103 & $<0.001$ \\
\hline FB3 & $\mathbf{( 0 . 8 6 9 )}$ & -0.394 & -0.050 & -0.175 & Reflective & 0.101 & $<0.001$ \\
\hline FB4 & $\mathbf{( 0 . 8 5 8 )}$ & 0.767 & -0.407 & -0.003 & Reflective & 0.102 & $<0.001$ \\
\hline FB5 & $\mathbf{( 0 . 7 8 5 )}$ & -0.274 & 0.218 & 0.484 & Reflective & 0.105 & $<0.001$ \\
\hline FB6 & $\mathbf{( 0 . 8 1 6 )}$ & -0.527 & 0.070 & 0.346 & Reflective & 0.103 & $<0.001$ \\
\hline FP1 & -0.244 & $\mathbf{( 0 . 8 5 8 )}$ & -0.149 & 0.223 & Reflective & 0.102 & $<0.001$ \\
\hline FP2 & -0.088 & $\mathbf{( 0 . 9 2 6 )}$ & 0.334 & 0.156 & Reflective & 0.099 & $<0.001$ \\
\hline FP3 & 0.153 & $\mathbf{( 0 . 9 0 9 )}$ & -0.319 & -0.121 & Reflective & 0.100 & $<0.001$ \\
\hline FP4 & 0.225 & $\mathbf{0 . 9 3 0 )}$ & -0.162 & 0.048 & Reflective & 0.099 & $<0.001$ \\
\hline FP5 & 0.164 & $\mathbf{0 . 9 1 6 )}$ & 0.225 & -0.267 & Reflective & 0.099 & $<0.001$ \\
\hline FP6 & -0.223 & $\mathbf{( 0 . 9 3 4 )}$ & 0.058 & -0.027 & Reflective & 0.099 & $<0.001$ \\
\hline PK1 & -0.026 & 0.154 & $\mathbf{( 0 . 8 7 5 )}$ & 0.370 & Reflective & 0.101 & $<0.001$ \\
\hline PK2 & 0.166 & -0.505 & $\mathbf{( 0 . 8 5 2 )}$ & -0.170 & Reflective & 0.102 & $<0.001$ \\
\hline PK3 & -0.136 & 0.340 & $\mathbf{0 . 8 6 9 )}$ & -0.206 & Reflective & 0.101 & $<0.001$ \\
\hline PDB1 & 0.298 & 0.091 & -0.079 & $\mathbf{( 0 . 9 0 0 )}$ & Reflective & 0.100 & $<0.001$ \\
\hline PDB2 & -0.016 & 0.154 & -0.240 & $\mathbf{( 0 . 8 8 0 )}$ & Reflective & 0.101 & $<0.001$ \\
\hline PDB3 & -0.290 & 0.126 & -0.091 & $\mathbf{( 0 . 8 5 0 )}$ & Reflective & 0.102 & $<0.001$ \\
\hline PDB4 & 0.047 & -0.362 & 0.275 & $\mathbf{( 0 . 8 9 3 )}$ & Reflective & 0.100 & $<0.001$ \\
\hline
\end{tabular}




\begin{tabular}{|c|c|c|c|c|c|c|c|}
\hline & FB & FP & PK & PDB & Type (as defined) & SE & P value \\
\hline PDB5 & -0.053 & -0.002 & 0.125 & $\mathbf{( 0 . 9 1 7 )}$ & Reflective & 0.099 & $<0.001$ \\
\hline
\end{tabular}

Sumber: Data Olahan

Hasil dari pengujian combine loadings and cross-loadings untuk Gen Y ditemukan bahwa indikator variabel untuk FP1 (Faktor Psikologi indikator 1), PK2 (Perilaku Konsumsi indikator 2), PK4 (Indikator Konsumsi indikator 4), PK5 (Perilaku Konsumsi indikator 5), FB6 (Faktor Budaya indikator 6), PBD4 (Perilaku Bertransaski Digital indikator 4), dan PBD5 (Perilaku Bertransaksi Digital indikator 5) memiliki nilai dibawah 0,70. Tabel 2 dibawah ini menyajikan hasil pengolahan data combine loadings and crossloadings.

Tabel 2. Indicator Loadings and Cross-Loadings Gen $X$

\begin{tabular}{|c|c|c|c|c|c|c|c|}
\hline & FB & FP & PK & PDB & Type (as defined) & SE & P value \\
\hline FB2 & $\mathbf{( 0 . 8 7 0 )}$ & 0.196 & -0.132 & -0.137 & Reflective & 0.101 & $<0.001$ \\
\hline FB3 & $\mathbf{( 0 . 9 1 8 )}$ & -0.094 & -0.063 & 0.014 & Reflective & 0.099 & $<0.001$ \\
\hline FB4 & $\mathbf{( 0 . 9 3 0 )}$ & -0.290 & 0.066 & 0.182 & Reflective & 0.099 & $<0.001$ \\
\hline FB5 & $\mathbf{( 0 . 7 6 7 )}$ & 0.241 & 0.145 & -0.082 & Reflective & 0.105 & $<0.001$ \\
\hline FP2 & -0.038 & $\mathbf{0 . 7 8 3 )}$ & 0.276 & -0.381 & Reflective & 0.105 & $<0.001$ \\
\hline FP3 & -0.074 & $\mathbf{( 0 . 8 3 4 )}$ & -0.235 & 0.432 & Reflective & 0.103 & $<0.001$ \\
\hline FP4 & 0.126 & $\mathbf{0 . 7 4 0 )}$ & -0.032 & -0.148 & Reflective & 0.106 & $<0.001$ \\
\hline FP5 & -0.227 & $\mathbf{0 . 8 0 7})$ & -0.001 & 0.207 & Reflective & 0.104 & $<0.001$ \\
\hline FP6 & 0.205 & $\mathbf{0 . 8 8 2})$ & 0.005 & -0.135 & Reflective & 0.101 & $<0.001$ \\
\hline PK1 & -0.056 & -0.093 & $\mathbf{0 . 9 1 9 )}$ & 0.164 & Reflective & 0.099 & $<0.001$ \\
\hline PK3 & 0.056 & 0.093 & $\mathbf{0 . 9 1 9 )}$ & -0.164 & Reflective & 0.099 & $<0.001$ \\
\hline PDB1 & -0.074 & 0.038 & 0.035 & $\mathbf{0 . 9 5 5 )}$ & Reflective & 0.098 & $<0.001$ \\
\hline PDB2 & -0.011 & 0.072 & -0.136 & $\mathbf{0 . 9 7 6}$ & Reflective & 0.097 & $<0.001$ \\
\hline PDB3 & 0.085 & -0.113 & 0.105 & $\mathbf{0 . 9 4 4 )}$ & Reflective & 0.098 & $<0.001$ \\
\hline
\end{tabular}

Sumber: Data Olahan

Hasil dari pengujian combine loadings and cross-loadings untuk Gen Z ditemukan bahwa indikator variabel untuk FB2 (Faktor Budaya indikator 2), FP1 (Faktor Psikologi indikator 1), FP5 (Faktor Psikologi indikator 5), PK1 (Perilaku Konsumsi indikator 1), PK2 (Perilaku Konsumsi indikator 2), PK4 (Indikator Konsumsi indikator 4), PK5 (Perilaku Konsumsi indikator 5), PBD2 (Perilaku Bertransaski Digital indikator 2), dan PBD3 (Perilaku Bertransaksi Digital indikator 3) memiliki nilai dibawah 0,70. Tabel 3. dibawah ini menyajikan hasil pengolahan data combine loadings and cross-loadings.

Tabel 3. Indicator Loadings and Cross-Loadings Gen $\mathrm{X}$

\begin{tabular}{|l|c|c|c|c|c|c|c|}
\hline & FB & FP & PK & PDB & $\begin{array}{c}\text { Type (as } \\
\text { defined) }\end{array}$ & SE & P value \\
\hline FB1 & $\mathbf{( 0 . 7 6 4 )}$ & -0.113 & 0.198 & -0.079 & Reflective & 0.105 & $<0.001$ \\
\hline FB3 & $\mathbf{( 0 . 7 9 3 )}$ & 0.363 & -0.064 & -0.440 & Reflective & 0.104 & $<0.001$ \\
\hline FB4 & $\mathbf{( 0 . 8 6 4 )}$ & 0.225 & -0.044 & 0.030 & Reflective & 0.101 & $<0.001$ \\
\hline FB5 & $\mathbf{( 0 . 7 3 6 )}$ & -0.368 & 0.051 & 0.335 & Reflective & 0.107 & $<0.001$ \\
\hline FB6 & $\mathbf{( 0 . 8 2 6 )}$ & -0.150 & -0.122 & 0.166 & Reflective & 0.103 & $<0.001$ \\
\hline FP2 & 0.215 & $\mathbf{( 0 . 7 8 1 )}$ & 0.145 & 0.016 & Reflective & 0.105 & $<0.001$ \\
\hline FP3 & -0.122 & $\mathbf{( 0 . 8 8 9 )}$ & -0.038 & 0.032 & Reflective & 0.100 & $<0.001$ \\
\hline FP4 & 0.073 & $\mathbf{0 . 8 0 8 )}$ & -0.087 & 0.025 & Reflective & 0.104 & $<0.001$ \\
\hline FP6 & -0.136 & $\mathbf{0 . 8 7 0}$ & -0.011 & -0.070 & Reflective & 0.101 & $<0.001$ \\
\hline PK3 & 0.000 & 0.000 & $\mathbf{( 1 . 0 0 0 )}$ & 0.000 & Reflective & 0.096 & $<0.001$ \\
\hline PDB1 & -0.091 & -0.356 & 0.110 & $\mathbf{( 0 . 8 4 7 )}$ & Reflective & 0.102 & $<0.001$ \\
\hline PDB4 & 0.085 & -0.206 & 0.074 & $\mathbf{( 0 . 8 1 8 )}$ & Reflective & 0.103 & $<0.001$ \\
\hline PDB5 & 0.009 & 0.588 & -0.192 & $\mathbf{0 . 7 9 9 )}$ & Reflective & 0.104 & $<0.001$ \\
\hline
\end{tabular}

Sumber: Data Olahan 
Pengujian berikutnya yang dilakukan adalah pengujian validitas terlihat dari hasil pengolahan data yang ditunjukkan oleh composite reliability (CR) dan conbach;s alpha (CA) dengan nilai hasil pengujian minimal atau lebih besar dari 0,70. Pengujian reliabilitas dilakukan dengan melihat hasil pengeolahan data yang ditunjukkan oleh average constructs exctracted (AVE) dengan nilai minimal atau lebih besar dari 0,50.

Tabel 4. Reliabilitas dan Validitas

\begin{tabular}{|c|c|c|c|c|c|c|c|}
\hline \multicolumn{8}{|c|}{ GEN X } \\
\hline Variabel & CR & CA & Min & Max & Median & AVE & VIF \\
\hline FB & 0.939 & 0.922 & -3.198 & 1.022 & 0.256 & 0.721 & 4.907 \\
\hline FP & 0.968 & 0.960 & -2.997 & 0.811 & 0.551 & 0.833 & 6.558 \\
\hline PK & 0.837 & 0.756 & -3.631 & 1.079 & 0.072 & 0.513 & 3.170 \\
\hline PDB & 0.949 & 0.933 & -4.657 & 0.675 & 0.457 & 0.789 & 2.237 \\
\hline \multicolumn{8}{|c|}{ GEN Y } \\
\hline Variabel & CR & CA & Min & Max & Median & AVE & VIF \\
\hline FB & 0.928 & 0.895 & -3.655 & 1.023 & 0.063 & 0.763 & 1.822 \\
\hline FP & 0.905 & 0.869 & -4.288 & 0.711 & 0.389 & 0.657 & 2.901 \\
\hline PK & 0.915 & 0.815 & -3.205 & 0.748 & 0.147 & 0.844 & 2.242 \\
\hline PDB & 0.971 & 0.956 & -3.233 & 0.593 & 0.593 & 0.919 & 1.896 \\
\hline \multicolumn{8}{|c|}{ GEN Z } \\
\hline Variabel & CR & CA & Min & Max & Median & AVE & VIF \\
\hline FB & 0.897 & 0.856 & -2.462 & 1.135 & 0.144 & 0.637 & 1.317 \\
\hline FP & 0.904 & 0.858 & -3.105 & 0.863 & 0.315 & 0.703 & 3.157 \\
\hline PK & 1.000 & 1.000 & -2.265 & 0.852 & 0.333 & 1.000 & 1.394 \\
\hline PDB & 0.862 & 0.759 & -4.095 & 0.727 & 0.253 & 0.675 & 2.698 \\
\hline
\end{tabular}

Sumber: Data Olahan

Diskriminat validitas ini dilakukan dengan menguji variabel penelitian yang digunakan dengan variabel itu sendiri. Hasil nilai pengujian variabel terhadap variabel tersebut harus lebih besar dibandingkan pengujian variabel tersebut dengan variabel lainnya.

Tabel 5. Discriminant Validity

\begin{tabular}{|c|c|c|c|c|}
\hline \multicolumn{5}{|c|}{ Gen X } \\
\hline & FB & FP & PK & PBD \\
\hline Faktor Budaya (FB) & $(0.849)$ & & & \\
\hline Faktor Psikologi (FP) & 0.888 & $(0.912)$ & & \\
\hline Perilaku Konsumsi (PK) & 0.749 & 0.800 & $(0.716)$ & \\
\hline Perilaku Bertransaksi Digital (PDB) & 0.605 & 0.705 & 0.698 & $(0.888)$ \\
\hline \multicolumn{5}{|l|}{ 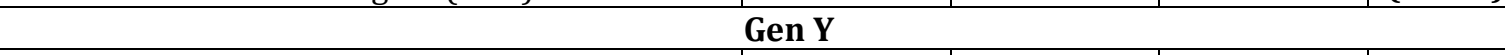 } \\
\hline & FB & FP & PK & PBD \\
\hline Faktor Budaya (FB) & $(0.874)$ & & & \\
\hline Faktor Psikologi (FP) & 0.620 & $(0.811)$ & & \\
\hline Perilaku Konsumsi (PK) & 0.617 & 0.707 & $(0.919)$ & \\
\hline Perilaku Bertransaksi Digital (PDB) & 0.480 & 0.682 & 0.529 & $(0.958)$ \\
\hline \multicolumn{5}{|c|}{ Gen Z } \\
\hline & FB & FP & PK & PBD \\
\hline Faktor Budaya (FB) & $(0.798)$ & & & \\
\hline Faktor Psikologi (FP) & 0.442 & $(0.838)$ & & \\
\hline Perilaku Konsumsi (PK) & 0.398 & 0.489 & $(1.000)$ & \\
\hline Perilaku Bertransaksi Digital (PDB) & 0.373 & 0.792 & 0.365 & $(0.822)$ \\
\hline
\end{tabular}

Sumber: Data Olahan 
Analisis jalur dilakukan analisis hubungan tidak langsung dengan menambahkan variabel mediasi yaitu perilaku konsumsi. Berikut ini disajikan gambar dari uji model fit hubungan langsung dan tidak langsung dari setiap variabel.

Model fit generasi X memiliki nilai uji APC 0,362 atau sama dengan 36,20\% dengan nilai $\mathrm{P}=0,001$, ARS 0,722 atau sama dengan $72,2 \%$ dengan nilai $\mathrm{P}<0,00.1$. Hasil pengujian untuk nilai VIF sebesar 4.445 dan nilai GoF sebesar 0,747 (kategori besar). Nilai koefisien jalur $\mathrm{H}_{1}$ sama dengan 0,010 dengan nilai $\mathrm{P}=0,471$, sedangkan nilai koefisien jalur $\mathrm{H}_{2 a}$ sama dengan 0,386 dengan nilai $\mathrm{P}<0.001$. Nilai koefisien jalur secara keseluruhan 0,55 dengan nilai $\mathrm{P}<0,001$.

Model fit generasi Y memiliki nilai uji nilai APC 0,314 atau sama dengan 31,40\% dengan nilai $\mathrm{P}=0,004$, ARS 0,500 atau sama dengan $50,0 \%$ dengan nilai $\mathrm{P}<0,00.1$. Hasil pengujian untuk nilai VIF sebesar 2.215 dan nilai GoF sebesar 0,647 (kategori besar). Nilai koefisien jalur $\mathrm{H}_{1 \mathrm{~b}}$ sama dengan 0,163 dengan nilai $\mathrm{P}=0,113$, sedangkan nilai koefisien jalur $\mathrm{H}_{2 \mathrm{~b}}$ sama dengan 0,533 dengan nilai $\mathrm{P}<0.001$. Nilai koefisien jalur secara keseluruhan 0,06 dengan nilai $\mathrm{P}=0.34$.

Model fit generasi Z memiliki nilai uji Nilai APC 0,323 atau sama dengan 32,30\% dengan nilai $P=0,003$, ARS 0,509 atau sama dengan $50,9 \%$ dengan nilai $P<0,00.1$. Hasil pengujian untuk nilai VIF sebesar 2.141 dan nilai GoF sebesar 0,619 (kategori besar). Nilai koefisien jalur $\mathrm{H}_{1 \mathrm{c}}$ sama dengan 0,063 dengan nilai $\mathrm{P}=0,324$, sedangkan nilai koefisien jalur $\mathrm{H}_{2 b}$ sama dengan 0,787 dengan nilai $\mathrm{P}<0.001$. Nilai koefisien jalur secara keseluruhan $-0,064$ dengan nilai $\mathrm{P}=0.321$.

Berikut ini tabel ringkasan pengujian hubungan langsung dan tidak langsung dari budaya (FB), transaksi digital (PBD), dan perilaku kosumsi (PK) dalam digunakan dalam penelitian ini.

Tabel 6. Ringakasan Hubungan Langsung dan Tidak Langsung

\begin{tabular}{|c|c|c|c|c|c|c|}
\hline \multicolumn{7}{|c|}{ Gen X } \\
\hline & \multicolumn{2}{|c|}{ Direct Effect } & \multirow{2}{*}{ Decision } & \multicolumn{2}{|c|}{ Indirect Effect } & \multirow{2}{*}{ Decision } \\
\hline & Koefisien Jalur & P-Value & & Koefisien Jalur & P-Value & \\
\hline FB-PBD & 0,01 & $\mathrm{P}=0,471$ & Ditolak & 0,158 & $P=0,050$ & Ditolak \\
\hline FP-PBD & 0,386 & $\mathrm{P}=0,001$ & Diterima & 0,317 & $\mathrm{P}<0,001$ & Diterima \\
\hline FB-PK & 0,286 & $\mathrm{P}=0,014$ & Ditolak & & & \\
\hline FP-PK & 0,573 & $\mathrm{P}=0,001$ & Diterima & & & \\
\hline PK-PBD & 0,553 & $\mathrm{P}<0,001$ & Diterima & & & \\
\hline \multicolumn{7}{|c|}{ Gen Y } \\
\hline & \multicolumn{2}{|c|}{ Direct Effect } & \multirow{2}{*}{ Decision } & \multicolumn{2}{|c|}{ Indirect Effect } & \multirow{2}{*}{ Decision } \\
\hline & Koefisien Jalur & P-Value & & Koefisien Jalur & P-Value & \\
\hline FB-PBD & $-0,137$ & $P=0,156$ & Ditolak & 0,045 & $\mathrm{P}=0,325$ & Ditolak \\
\hline FP-PBD & 0,525 & $\mathrm{P}<0,001$ & Diterima & 0,069 & $\mathrm{P}=0,24$ & Ditolak \\
\hline FB-PK & 0,308 & $\mathrm{P}=0,009$ & Ditolak & & & \\
\hline FP-PK & 0,475 & $\mathrm{P}<0,001$ & Diterima & & & \\
\hline PK-PBD & 0,146 & $\mathrm{P}=0,14$ & Ditolak & & & \\
\hline \multicolumn{7}{|c|}{ Gen Z } \\
\hline & \multicolumn{2}{|c|}{ Direct Effect } & \multirow{2}{*}{ Decision } & \multicolumn{2}{|c|}{ Indirect Effect } & \multirow{2}{*}{ Decision } \\
\hline & Koefisien Jalur & P-Value & & Koefisien Jalur & P-Value & \\
\hline FB-PBD & 0,063 & $\mathrm{P}=0,324$ & Ditolak & $-0,018$ & $\mathrm{P}=0,428$ & Ditolak \\
\hline FP-PBD & 0,787 & $\mathrm{P}<0,001$ & Diterima & $-0,027$ & $\mathrm{P}=0.392$ & Ditolak \\
\hline FB-PK & 0,28 & $\mathrm{P}=0,016$ & Ditolak & & & \\
\hline FP-PK & 0,422 & $\mathrm{P}<0,001$ & Diterima & & & \\
\hline
\end{tabular}


\begin{tabular}{|l|l|l|l|l|l|} 
PK-PBD & $-0,064$ & $\mathrm{P}=0,321$ & Ditolak & & \\
\hline
\end{tabular}

Sumber: Data Olahan

Hasil pengujian hipotesis menggunakan variabel mediasi bagian pembahasan ini merujuk pada Carrión et al., (2017) yang menjelaskan pengujian menggunakan variabel mediasi dilakukan untuk melihat hubungan langsung dan tidak langsung dari variabel yang digunakan. Variabel mediasi dapat memediasi secara penuh, mediasi secara parsial, dan dapat tidak memediasi.

Pengujian $\mathrm{H}_{1 a}$ menjelaskan bahwa tidak ada hubungan langsung faktor budaya terhadap transaksi digital pada generasi $\mathrm{X}$ serta tidak ada hubungan tidak langsung antara

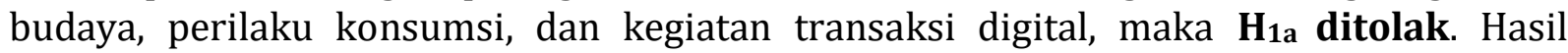
pengujian $\mathrm{H}_{1 \mathrm{~b}}$ menjelaskan bahwa bahwa tidak ada hubungan langsung faktor budaya terhadap keinginan untuk bertransaksi digital pada generasi Y serta tidak ada hubungan tidak langsung antara budaya, perilaku, dan kegiatan transaksi digital, maka H1b ditolak. Hasil pengujian $\mathrm{H}_{1 c}$ menjelaskan bahwa bahwa tidak ada hubungan langsung faktor budaya terhadap keinginan untuk bertransaksi digital pada generasi $\mathrm{Z}$ serta tidak ada hubungan tidak langsung antara budaya, perilaku, dan kegiatan transaksi digital, maka $\mathbf{H}_{1 \mathbf{c}}$ ditolak.

Pengujian untuk $\mathrm{H}_{2 a}$ menjelaskan bahwa ada hubungan langsung dan signifikan antara faktor psikologis dengan kegiatan transaksi digital generasi $\mathrm{X}$, dan diperoleh hubungan tidak langsung yang signifikan antara faktor psikologis, perilaku konsumsi, dan kegiatan transaksi digital generasi $\mathrm{X}$ sehingga hipotesis mediasi $\mathrm{H}_{2 a}$ ditolak. Hasil Pengujian $\mathrm{H}_{2 b}$ menjelaskan bahwa ada hubungan langsung dan signifikan antara faktor psikologis dengan kegiatan transaksi digital generasi $\mathrm{Y}$, dan tidak diperoleh hubungan tidak langsung yang signifikan antara faktor psikologis, perilaku konsumsi, dan kegiatan transaksi digital generasi $\mathrm{Y}$ sehingga bentuk mediasi adalah mediasi penuh dan $\mathbf{H}_{\mathbf{2 b}}$ diterima. Hasil Pengujian $\mathrm{H}_{2 c}$ menjelaskan bahwa ada hubungan langsung dan signifikan antara faktor psikologis dengan kegiatan transaksi digital generasi Z, dan tidak diperoleh hubungan tidak langsung yang signifikan antara faktor psikologis, perilaku konsumsi, dan kegiatan transaksi digital generasi $\mathrm{Z}$ sehingga bentuk mediasi adalah mediasi penuh dan $\mathrm{H}_{2 c}$ diterima.

\section{SIMPULAN}

Berdasarkan pembahasan yang telah dijelaskan maka diperoleh kesimpulan bahwa, kegiatan bertransaksi secara digital untuk generasi $\mathrm{X}, \mathrm{Y}$, dan $\mathrm{Z}$ tidak dipengaruhi oleh faktor budaya meskipun diberikan variabel perilaku konsumsi untuk memediasi keduanya. Faktor psikologi generasi X menjadi hal yang mempengaruhi aktivitas transaksi digital, sehingga tidak perlu dimediasi oleh faktor perilaku konsumsi. Hubungan yang berbeda terjadi pada generasi Y dan Z. Generasi Y dan Z dipengaruhi oleh faktor psikologi dalam bertransaksi secara digital dan perilaku konsumsi menjadi variabel yang memediasi generasi Y dan Z untuk melakukan transaksi digital. Penelitian selanjutnya sebaiknya menambahkan variabel lainnya untuk lebih mengembangkan model perilaku transaksi digital antar generasi. Peneliti selanjutnya juga dapat lebih memperbanyak populasi dan sampel yang digunakan, agar lebih memperkaya hasil penelitian.

\section{UCAPAN TERIMAKASIH}

Penulis mengucapkan terima kasih kepada Lembaga Penelitian dan Pengabdian kepada Masyarakat Universitas Pembangunan Nasional Veteran Yogyakarta, Indonesia yang telah memberikan dukungan dana untuk penelitian ini. 


\section{DAFTAR PUSTAKA}

Apuke, O. D. (2017). Quantitative Research Methods: A Synopsis Approach. Kuwait Chapter of Arabian Journal of Business and Management Review, 6(11), 40-47. https://doi.org/10.12816/0040336

Auf, M. A. A., Meddour, H., Saoula, O., \& Majid, A. H. A. (2018). Consumer buying behaviour: The roles of price, motivation, perceived culture importance, and religious orientation. Journal of Business and Retail Management Research, 12(4), 177-186. https://doi.org/10.24052/jbrmr/v12is04/art-18

Bencsik, A., Juhász, T., \& Horváth-Csikós, G. (2016). Y and Z Generations at Workplaces. Journal of Competitiveness, 8(3), 90-106. https://doi.org/10.7441/joc.2016.03.06

Carrión, G. C., Nitzl, C., \& Roldán, J. L. (2017). Mediation analyses in partial least squares structural equation modeling: Guidelines and empirical examples. Partial Least Squares Path Modeling: Basic Concepts, Methodological Issues and Applications, (January), 173-195. https://doi.org/10.1007/978-3-31964069-3_8

Disman, D., Ali, M., \& Syaom Barliana, M. (2017). the Use of Quantitative Research Method and Statistical Data Analysis in Dissertation: an Evaluation Study. International Journal of Education, 10(1), 46. https://doi.org/10.17509/ije.v10i1.5566

Filotto, U., Caratelli, M., \& Fornezza, F. (2021). Shaping the digital transformation of the retail banking industry. Empirical evidence from Italy. European Management Journal, 39(3), 366-375. https://doi.org/10.1016/j.emj.2020.08.004

Hanninen, M. (2020). Digital Transaction Platforms; Form, Mechanisms and Outcomes (Aalto University). Retrieved from http://urn.fi/URN:ISBN:978-952-60-3804-9

Iskandar. (2021). Ini Daftar Dompet Digital yang Paling Banyak Digunakan Orang Indonesia - Tekno Liputan6.com. Retrieved June 26, 2021, from liputan6.com website: https://www.liputan6.com/tekno/read/4472006/ini-daftar-dompet-digital-yang-paling-banyakdigunakan-orang-indonesia

Kasasa. (2021). Boomers, Gen X, Gen Y, and Gen Z Explained. Retrieved March 1, 2021, from Kasasa.com website: https://www.kasasa.com/articles/generations/gen-x-gen-y-gen-z

Kulkarni, D. S., Varma, D. A. J., \& V, D. R. P. (2021). A Literature Study Of Consumer Perception Towards Digital Payment Mode In India. Psychology and Education Journal, 58(1), 3304-3319. https://doi.org/10.17762/pae.v58i1.1270

Nguyen, D. H., de Leeuw, S., \& Dullaert, W. E. H. (2018). Consumer Behaviour and Order Fulfilment in Online Retailing: A Systematic Review. International Journal of Management Reviews, 20(2), 255-276. https://doi.org/10.1111/ijmr.12129

Nilekani, S. N., Khan, S. H. R., Sansi, S. K., Sharma, S. A., \& Jain, S. S. (2019). Report Of The High Level Committe on Deepening of Digital Payment. Mumbai.

Otoritas Jasa Keuangan. (2017). Peraturan Otoritas Jasa Keuangan Nomor /Pojk.03/2017 Tentang Penyelenggaraan Layanan Perbankan Digital Oleh Bank Umum. Journal of Chemical Information and Modeling, 53(9), 1689-1699. Retrieved from file:///C:/Users/User/Downloads/fvm939e.pdf

Park, D. H. (2019). Virtuality changes consumer preference: The effect of transaction virtuality as psychological distance on consumer purchase behavior. Sustainability (Switzerland), 11(23). https://doi.org/10.3390/su11236618

Peña-García, N., Gil-Saura, I., Rodríguez-Orejuela, A., \& Siqueira-Junior, J. R. (2020). Purchase intention and purchase behavior online: A cross-cultural approach. Heliyon, 6(6). https://doi.org/10.1016/j.heliyon.2020.e04284

Putra, Y. S. (2016). THEORITICAL REVIEW: TEORI PERBEDAAN GENERASI. Among Makarti, Vol.9 No.1(1952), 123-134.

Rachmawati, W. I., Kartawinata, B. R., Wijaya, C., \& Hasbi, I. (2020). Factors Analysis that Affecting the Intention to Use Digital Payment (Case Study on OVO Users in Jakarta, Bogor, Depok, Tangerang, Bekasi). KnE Social Sciences, 2020, 290-302. https://doi.org/10.18502/kss.v4i6.6605

Rapp, A., Tirassa, M., \& Tirabeni, L. (2019). Rethinking technologies for behavior change: A view from the inside of Human change. ACM Transactions on Computer-Human Interaction, 26(4). https://doi.org/10.1145/3318142

Saragih, S. P., \& Nopriadi, N. (2019). Pengaruh Budaya Terhadap Actual Use Digital Payment System Pada Pelaku UMKM di Kota Batam. Journal of Applied Informatics and Computing, 3(2), 63-67. https://doi.org/10.30871/jaic.v3i2.1646

Sarkar, R. (2018). Digitalization and its impact on financial transactions in India. Frontiers of Digital Finance, (August). Retrieved from https://www.researchgate.net/publication/334947948_Digitalization_and_its_impact_on_financial_t 
ransactions_in_India

Sipayo. (2017). Karakter 4 Generasi, Baby Boomer, X, Y, dan Z dalam Dunia Pekerjaan. Retrieved March 2, 2021, from sipayo.com website: https://www.sipayo.com/2017/05/karakter-4-generasi-babyboomer-x-y-dan-z-dalam-dunia-pekerjaan.html

Suyudi, T. (2021). Tiga Tren E-commerce di 2021 yang Perlu Kita Ketahui - ItWorks. Retrieved June 26, 2021, from It Works website: https://www.itworks.id/36819/tiga-tren-e-commerce-di-2021-yangperlu-kita-ketahui.html

Syahadiyanti, L., \& Subriadi, A. P. (2018). Diffusion of Innovation Theory Utilization Online Financial Transaction: Literature Review. International Journal of Economics and Financial Issues, 8(3), 219226.

Trisnani, S. A., Adriyai, A. D., Wandansari, R. A., \& Isthika, W. (2019). Consumption behavior and the lack of financial literacy among teens. Journal of Islamic Economics, Management, and Business, 1(1), 191-206. https://doi.org/10.21580/jiemb.2019.1.1.3705

Victor, V., Thoppan, J. J., Nathan, R. J., \& Maria, F. F. (2018). Factors influencing consumer behavior and prospective purchase decisions in a dynamic pricing environment-an exploratory factor analysis approach. Social Sciences, 7(9). https://doi.org/10.3390/socsci7090153

Wang, Y., Wang, Q.-W., Tao, Y.-Y., \& Xie, W.-W. (2021). Empirical Study of Consumption Behavior of College Students under the Influence of Internet-based Financing Services. Procedia Computer Science, 187(2019), 152-157. https://doi.org/10.1016/j.procs.2021.04.046 